\title{
Facile preparation and conversion of 4,4,4-trifluorobut-2-yn-1- ones to aromatic and heteroaromatic compounds
}

\author{
Takashi Yamazaki ${ }^{*}$ Yoh Nakajima, Minato lida and Tomoko Kawasaki-Takasuka
}

\author{
Full Research Paper \\ Address: \\ Division of Applied Chemistry, Institute of Engineering, Tokyo \\ University of Agriculture and Technology, 2-24-16 Nakamachi, \\ Koganei 184-8588, Japan \\ Email: \\ Takashi Yamazaki* - tyamazak@cc.tuat.ac.jp \\ * Corresponding author \\ Keywords: \\ $\mathrm{CF}_{3}$-containing propargylic alcohols; $\mathrm{CF}_{3}$-containing ynones; \\ oxidation; pyrimidines; salicylate derivatives
}

Open Access

\author{
Beilstein J. Org. Chem. 2021, 17, 132-138. \\ https://doi.org/10.3762/bjoc. 17.14 \\ Received: 20 October 2020 \\ Accepted: 18 December 2020 \\ Published: 15 January 2021 \\ This article is part of the thematic issue "Organo-fluorine chemistry V". \\ Guest Editor: D. O'Hagan \\ (c) 2021 Yamazaki et al.; licensee Beilstein-Institut. \\ License and terms: see end of document.
}

\begin{abstract}
The concise preparation of 4,4,4-trifluorobut-2-yn-1-ones by the oxidation of the readily accessible corresponding propargylic alcohols as well as their utilization as Michael acceptors for the construction of aromatic and heteroaromatic compounds are reported.
\end{abstract}

\section{Introduction}

It is well known that the incorporation of a fluorine atom or a fluorine-containing group into organic compounds sometimes affects their original biological activities [1-3], and thus the development of methods for the construction of such molecules with this atom or group is an important task. During our research in the field of fluorine chemistry, we have previously developed methods to get convenient access to $\mathrm{CF}_{3}$-containing propargylic alcohols 1 using 2-bromo-3,3,3-trifluoropropene [4,5] as well as 1-chloro-3,3,3-trifluoropropene [6] as a substrate and to utilize 1 by way of a variety of routes [7-14]. Recently, we turned our attention to oxidized propargyl alcohols, namely ynones $\mathbf{2}$, because of the interesting structure with two strongly electron-withdrawing moieties, resulting in a high electrophilicity. However, only a few methods have been reported thus far for their preparation [15-20], including one that appeared in 2020 [21]. However, they suffer from problems, such as the formation of the desired product $\mathbf{2}$ only as regioisomeric mixtures $[15,17]$ or the applicability to only one substrate without any extension to other related compounds $[16,18$ 20]

Aromatic and heteroaromatic compounds are recognized as useful intermediates, and as pointed out above, the expected high electrophilicity of $\mathbf{2}$ was considered to allow the utilization as efficient Michael acceptors. Actually, this was the case, and the Sandford group clarified the high potency of these compounds for the conjugate addition of $\mathrm{N}$ - as well as O-nucleophiles [21]. On the basis of such an idea, we tried two routes to gain access to 1) 4-substituted 6-(trifluoromethyl)salicylate derivatives (C-nucleophiles) and 2) 6-substituted 4-(trifluoromethyl)pyrimidines (N-nucleophiles), both in a concise fashion, with the full details, including the preparation of $\mathbf{2}$, being reported herein. 


\section{Results and Discussion}

Investigations on the reaction conditions were carried out for the oxidation of propargylic alcohols $\mathbf{1}$, which were readily accessible by our already reported procedure $[4,19]$ as well as by the ones developed by other groups [22,23]. In spite of the previous unfavorable results for the oxidative transformation of 1a by $\mathrm{MnO}_{2}$ as well as other oxidants [18,23], $\mathrm{MnO}_{2}$ was selected due to the low cost and convenient handling. After a number of trials aimed at optimizing the reaction conditions, the unexpectedly smooth conversion of $\mathbf{1 a}$ to $\mathbf{2 a}$ was realized. Although it was reported $[18,23]$ that only a small amount of $\mathbf{2 a}$ was confirmed after the reaction of $1 \mathbf{a}$ with 10 equiv of $\mathrm{MnO}_{2}$ at ambient temperature after 1 day, the same amount of oxidant actually led to the complete conversion after only $4 \mathrm{~h}$ at room temperature. In this instance, for the clean preparation of the desired compound $\mathbf{2 a}$, the important point was to initiate this oxidation process at $0{ }^{\circ} \mathrm{C}$, followed by warming to ambient temperature. With this intriguing result in hand, the oxidation of the other substrates 1 was performed under similar reaction condition, the results of which are summarized in Table 1.

We reported the yield as determined by ${ }^{19} \mathrm{~F}$ NMR spectroscopy rather than after purification because of the inherent instability of 2 on silica gel, causing partial decomposition. The crude mixture proved to be substantially pure, and thus $\mathbf{2 c}$ and $\mathbf{2 d}$ afforded appropriate analytical data, including NMR $\left({ }^{1} \mathrm{H},{ }^{13} \mathrm{C}\right.$, and ${ }^{19} \mathrm{~F}$ ), IR, as well as high-resolution MS data. This process allowed us to obtain the required ynones $\mathbf{2}$ as long as the residue $\mathrm{R}$ was aromatic, while with an aliphatic substituent in this position, a full conversion was not observed even after a prolonged reaction period and at a higher temperature, and such conditions seemed to evoke the degradation of the products $\mathbf{2}$ to some extent. This was not the case for the Dess-Martin periodinane oxidation and the propargylic alcohols with $\mathrm{C}_{7} \mathrm{H}_{15}$ as the residue $\mathrm{R}^{1}$ by Hoye et al. [15] and $\mathrm{C}_{9} \mathrm{H}_{19}$ as the residue $\mathrm{R}^{1}$ by the Sandford group [21], who recorded $80 \%$ and $76 \%$ isolated yield, respectively, of the corresponding ketones. Because these compounds were previously isolated inconveniently by preparative GLC [15] or distillation [17,19], we decided to employ them without further purification.

The Michael addition reactions were then carried out under basic conditions for the ynone 2a thus obtained, which, to our astonishment, was found to be relatively rare even for the nonfluorinated counterparts (Table 2) [24-28].

As expected for this model system, a very efficient addition was observed within a period of $0.5 \mathrm{~h}$ at $0{ }^{\circ} \mathrm{C}$, leading to an isolated yield of $69 \%$ for the adduct $3 \mathbf{a a}$ when 1.5 equiv of acetylacetone and $\mathrm{NaH}$ in $\mathrm{Et}_{2} \mathrm{O}$ were used (Table 2, entries 1-3), which unambiguously demonstrated the high potency of $\mathbf{2 a}$ as a Michael acceptor. Stronger bases, such as $\mathrm{NaH}$ and $t$-BuOK seemed to be preferable (Table 2, entries 3 and 6), and amines such as DBU and 1,1,3,3-tetramethylguanidine (TMG) were found to be insufficient (Table 2, entries 10 and 11). Judging from the possible mechanism, this process was considered to proceed under the action of a catalytic amount of a base, and only $2 \mathrm{~mol} \%$ of $t$-BuOK led to the formation of the desired adduct 3aa as a sole stereoisomer in $84 \%$ isolated yield under the same reaction conditions (Table 2, entries 6-8). The $E$-stereochemistry of 3aa was deduced from the NMR data of structurally similar compounds [29] on the basis of 1) comparison of the chemical shift of the $\mathrm{CF}_{3}$ group and 2) the absence of a coupling between the vinylic and allylic protons. In order to explore other nucleophiles, we employed 1,3-diketones, such as 5-methylhexane-1,3-dione and 5,5-dimethylhexane-1,3-dione (that is, one of the two methyl groups in acetylacetone was formally substituted for an isopropyl or a $t$-Bu moiety, respective-

Table 1: Oxidation of propargylic alcohols $1 .^{\mathrm{a}}$

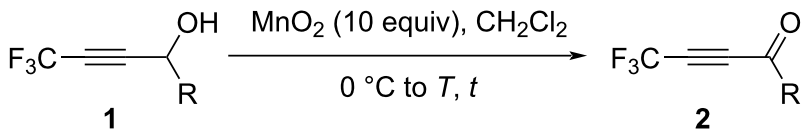

\begin{tabular}{cccccc}
\hline entry & $\mathrm{R}$ & $T\left({ }^{\circ} \mathrm{C}\right)$ & $t(\mathrm{~h})$ & product & 19F NMR yield $(\%)$ \\
\hline 1 & $\mathrm{Ph}$ & $\mathrm{rt}$ & 4 & $\mathbf{2 a}$ & $\mathbf{2 a}(100)$ \\
2 & $4-\left(\mathrm{MeO}^{\mathrm{b}} \mathrm{C}_{6} \mathrm{H}_{4}\right.$ & $\mathrm{rt}$ & 2.5 & $\mathbf{2 b}$ & $93(100)$ \\
3 & $4-\mathrm{MeC}_{6} \mathrm{H}_{4}$ & $\mathrm{rt}$ & 3 & $\mathbf{2 c}$ & $\mathbf{2 d}(100)$ \\
4 & $4-\mathrm{BrC}_{6} \mathrm{H}_{4}$ & $\mathrm{rt}$ & 2 & $\mathbf{2 e}$ & $58(93)$ \\
5 & $\mathrm{PhCH}_{2} \mathrm{CH}_{2}$ & reflux & 20 & $\mathbf{2 e}$ & $35(48)$ \\
$6 \mathrm{C}$ & $\mathrm{PhCH}_{2} \mathrm{CH}_{2}$ & reflux & 20 & $25(80)$ & \\
\hline
\end{tabular}

a 1 was added to a $\mathrm{CH}_{2} \mathrm{Cl}_{2}$ solution of $\mathrm{MnO}_{2}$ at $0^{\circ} \mathrm{C}$, and the mixture was stirred with gradually warming to a defined temperature for a defined reac-

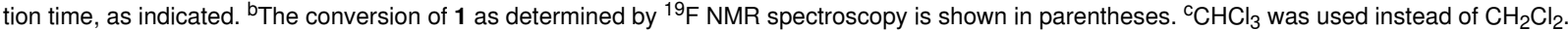


Table 2: Michael addition of acetylacetone to $\mathbf{2 a}$.

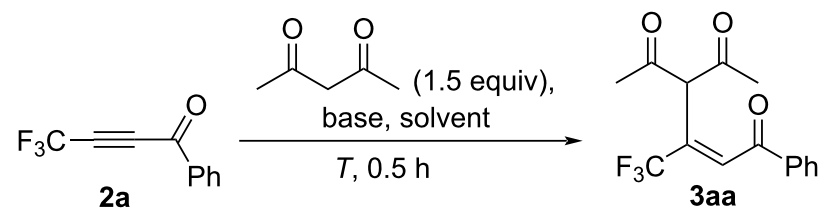

\begin{tabular}{|c|c|c|c|c|}
\hline entry & base (equiv) & solvent & $T\left({ }^{\circ} \mathrm{C}\right)$ & ${ }^{19} \mathrm{~F}$ NMR yield ${ }^{\mathrm{a}}(\%)$ \\
\hline 1 & $\mathrm{NaH}(1.5)$ & THF & 0 & 53 \\
\hline 2 & $\mathrm{NaH}(1.5)$ & DMF & 0 & 34 \\
\hline 3 & $\mathrm{NaH}(1.5)$ & $\mathrm{Et}_{2} \mathrm{O}$ & 0 & $76(69)$ \\
\hline 4 & $\mathrm{NaH}(1.5)$ & $\mathrm{Et}_{2} \mathrm{O}$ & -40 & 72 \\
\hline 5 & $\mathrm{NaH}(1.5)$ & $\mathrm{Et}_{2} \mathrm{O}$ & rt & 61 \\
\hline 6 & $t$-BuOK (1.5) & $\mathrm{Et}_{2} \mathrm{O}$ & 0 & $68(67)$ \\
\hline 7 & $t$-BuOK (0.1) & $\mathrm{Et}_{2} \mathrm{O}$ & 0 & 77 \\
\hline 8 & $t$-BuOK (0.02) & $\mathrm{Et}_{2} \mathrm{O}$ & 0 & $94(84)$ \\
\hline 9 & $t$-BuOK (0.02) & $t-\mathrm{BuOH}$ & 30 & 78 \\
\hline 10 & DBU $(0.1)$ & $\mathrm{Et}_{2} \mathrm{O}$ & 0 & 33 \\
\hline 11 & $\mathrm{TMG}^{\mathrm{b}}(0.1)$ & $\mathrm{Et}_{2} \mathrm{O}$ & 0 & 14 \\
\hline
\end{tabular}

aThe isolated yield is shown in parentheses. ${ }^{b} 1,1,3,3-$ Tetramethylguanidine.

ly), but no reaction was observed at all. The conjugate addition of amines to this type of ynone has already been reported [21], where the authors pointed out the significant slowdown of the reaction rate when tert-butylamine was employed, which was considered to be a reflection of the sensitivity of ynones 2 towards steric hindrance.
Because appropriate conditions for the initial Michael addition reactions were thus determined, further conversion to the benzene derivative $4 \mathbf{a a}$ was also performed (Table 3).

First of all, 3aa was introduced to a $t$ - $\mathrm{BuOH}$ solution of 2 equiv of $t$-BuOK to afford the desired product 4aa in a high yield, and

Table 3: Investigation of the cyclization conditions for 3aa.<smiles>CC(=O)C(C(C)=O)/C(=C\C(=O)P)C(F)(F)F</smiles>

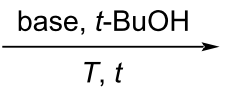<smiles>CC(=O)c1c(O)cc([PH2+])cc1C(F)(F)F</smiles>

\begin{tabular}{ccccc}
\hline entry & base (equiv) & $T\left({ }^{\circ} \mathrm{C}\right)$ & $t(\mathrm{~h})$ & ${ }^{19} \mathrm{~F}$ NMR yield of 4aa ${ }^{\mathrm{a}}(\%)$ \\
\hline 1 & $t$-BuOK (0.5) & 60 & 4 & $7(49)$ \\
2 & $t$-BuOK (1.0) & 60 & 4 & $13(81)^{\mathrm{b}}\{8\}$ \\
3 & $t$-BuOK (2.0) & 60 & 4 & $85(<1)$ \\
4 & $t$-BuOK (3.0) & 60 & 4 & $>99(0)$ \\
5 & $t$-BuOK (3.0) & 60 & 2 & $>99(0)$ \\
6 & $t$-BuOK (3.0) & 30 & 2 & $>99(0)\{84\}$ \\
$7^{\mathrm{c}}$ & $t$-BuOK (3.0) & 30 & 2 & $>99(0)$ \\
8 & $t$-BuONa (3.0) & 30 & 2 & $58(0)$ \\
9 & $t$-BuOLi (3.0) & 30 & 3 & $66(3)$ \\
$10^{\mathrm{d}}$ & EtONa (3.0) & 30 & 2 & $0(0)$ \\
$11^{\mathrm{d}}$ & EtONa (3.0) & 60 & 6 & $18(15)$ \\
\hline
\end{tabular}

${ }^{\text {aThe }}{ }^{19} \mathrm{~F}$ NMR yield of $\mathbf{5 a}$ and the isolated yield of $\mathbf{4 a a}$ are shown in parentheses and braces, respectively. ${ }^{\mathrm{b}}$ Isolated yield of $\mathbf{5 a}$. ${ }^{\mathrm{C}} \mathrm{Et} \mathrm{t}_{2} \mathrm{O}$ was used instead of $t-\mathrm{BuOH}$. dEtOH was used instead of $t-\mathrm{BuOH}$. 
an increase in the amount of this base to 3 equiv led to the complete conversion of the substrate 3aa (Table 3, entries 3 and 4). This trend was followed even when the temperature was decreased to $30^{\circ} \mathrm{C}$ and the reaction time was $2 \mathrm{~h}$, furnished $4 \mathrm{aa}$ in a $84 \%$ yield (Table 3, entries 6 and 7). The use of the corresponding lithium and sodium tert-butoxides was found to afford a lower yield, which clarified the importance of the ionic character of the base (Table 3, entries 8 and 9).

For the present transformation, $\mathrm{Hu}$ and Guan already reported a similar type of ring closure of the substrate $\mathbf{3 f a}$ [30], which allowed the conversion to the phenolic product $\mathbf{5 f}$ as a result of the cyclization and was accompanied by deacetylation under the conditions depicted in Scheme 1 [31-33].<smiles>CC(=O)C(C(C)=O)/C(=C\C(=O)C(C)(C)C)C(F)(F)F</smiles>
$3 f a$

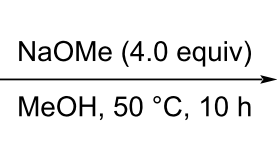

$\mathrm{F}_{3} \mathrm{C}$ 5f, $87 \%$ yield
Scheme 1: Deacetylative cyclization of $\mathbf{3 f a}$

In our case, it was quite interesting to note that the deacylated product 5a was also obtained as the major product when an equimolar or lesser amount of $t$-BuOK was employed (Table 3 , entries 1 and 2), along with formation of a minor amount of 4aa. Moreover, when the isolated product 4aa was subjected to the conditions shown in Table 3, entry 4, no reaction was observed at all, with recovery of $\mathbf{4 a a}$, which clearly demonstrated that the deacetylation step had occurred before the conversion to $4 \mathbf{a a}$. In the present cyclization, the ionic character of the alk- oxide seemed to be an important factor, and the corresponding lithium and sodium salts did not aid the reaction satisfactory. Moreover, EtONa was found to be inappropriate for this protocol (Table 3, entries 10 and 11).

Determination of the appropriate conditions both for Michael addition as well as cyclization/aromatization reactions allowed us to explore a brief scope and limitation of the present reaction by using four representative types of crude ynones 2 starting from the conjugate addition step either with acetylacetone or ethyl acetoacetate (Table 4).

In all instances, the desired products $\mathbf{4}$ were obtained in good to excellent yield without contamination by the deacetylated products 5 .

With the success of the regiospecific formation of 4-substituted 6-(trifluoromethyl)salicylate derivatives $\mathbf{4}$, as shown in Table 4, the application of ynones $\mathbf{2}$ was demonstrated at the next stage for the construction of a variety of pyrimidine derivatives, $\mathbf{6}$, using amidines including guanidine [34]. First of all, various bases were employed for the reaction of the model substrate $\mathbf{2 a}$. During initial testing, guanidine hydrochloride at $25^{\circ} \mathrm{C}$ for $4 \mathrm{~h}$ in acetonitrile (Table 5, entries 1-7) as well as sodium carbonate were found to be adequate (Table 5, entry 5).

A comparison of the results in Table 5, entries 8-11 vs entry 5 led to the determination that the adequate solvent was acetonitrile. After screening the reaction time and temperature (Table 5, entries $12-15$ vs entry 5), we eventually selected the conditions as shown in Table 5 , entry 14 , which included heating the reaction mixture at $80{ }^{\circ} \mathrm{C}$ for $8 \mathrm{~h}$ in $\mathrm{MeCN}$, furnishing the desired pyrimidine $6 \mathbf{a a}$ in $60 \%$ isolated yield.

Table 4: Preparation of the trifluoromethylated salicylate derivatives 4.

\begin{tabular}{|c|c|c|c|c|}
\hline & $\mathrm{F}_{3} \mathrm{C}=$ & & $\begin{array}{l}1.5 \text { equiv), } \\
\mathrm{C}, 0.5 \mathrm{~h} \\
1.5 \text { equiv), } \\
3.0 \text { equiv), }\end{array}$ & \\
\hline entry & $\mathrm{R}^{1}$ & $\mathrm{R}^{2}$ & product & isolated yield (\%) \\
\hline 1 & $\mathrm{Ph}$ & $\mathrm{Me}$ & $4 a a$ & 74 \\
\hline 2 & $\mathrm{Ph}$ & $\mathrm{EtO}$ & $4 a b$ & 80 \\
\hline 3 & 4- $(\mathrm{MeO}) \mathrm{C}_{6} \mathrm{H}_{4}$ & $\mathrm{Me}$ & $4 \mathrm{ba}$ & 67 \\
\hline 4 & 4- $(\mathrm{MeO}) \mathrm{C}_{6} \mathrm{H}_{4}$ & $\mathrm{EtO}$ & $4 b b$ & 73 \\
\hline 5 & $4-\mathrm{Me}-\mathrm{C}_{6} \mathrm{H}_{4}$ & $\mathrm{Me}$ & $4 c a$ & 68 \\
\hline 6 & $4-\mathrm{Me}-\mathrm{C}_{6} \mathrm{H}_{4}$ & $\mathrm{EtO}$ & $4 c b$ & 75 \\
\hline 7 & $4-\mathrm{Br}-\mathrm{C}_{6} \mathrm{H}_{4}$ & $\mathrm{Me}$ & 4da & 70 \\
\hline 8 & $4-\mathrm{Br}-\mathrm{C}_{6} \mathrm{H}_{4}$ & $\mathrm{EtO}$ & $4 d b$ & 54 \\
\hline
\end{tabular}


Table 5: Preparation of trifluoromethylated pyrimidine derivatives 6 aa.

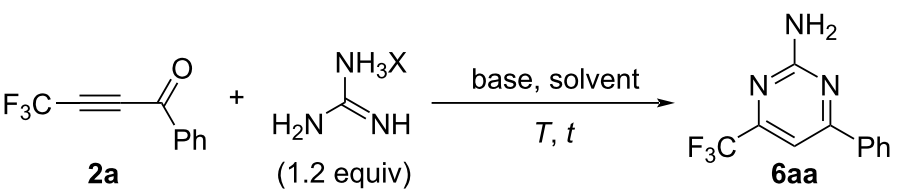

$2 a$

(1.2 equiv)

6aa

\begin{tabular}{|c|c|c|c|c|c|c|}
\hline \multirow[t]{2}{*}{ entry } & \multirow[t]{2}{*}{ base } & \multirow[t]{2}{*}{ solvent } & \multirow[t]{2}{*}{$T\left({ }^{\circ} \mathrm{C}\right)$} & \multirow[t]{2}{*}{$t(\mathrm{~h})$} & \multicolumn{2}{|c|}{${ }^{19}$ F NMR yielda (\%) } \\
\hline & & & & & 6aa & byproducts \\
\hline 1 & $\mathrm{KOt}-\mathrm{Bu}$ & $\mathrm{CH}_{3} \mathrm{CN}$ & 25 & 4 & 8 & 54 \\
\hline 2 & $\mathrm{NaOEt}$ & $\mathrm{CH}_{3} \mathrm{CN}$ & 25 & 4 & 15 & 9 \\
\hline 3 & DBU & $\mathrm{CH}_{3} \mathrm{CN}$ & 25 & 4 & 3 & 17 \\
\hline 4 & $\mathrm{~K}_{2} \mathrm{CO}_{3}$ & $\mathrm{CH}_{3} \mathrm{CN}$ & 25 & 4 & 28 & 4 \\
\hline 5 & $\mathrm{Na}_{2} \mathrm{CO}_{3}$ & $\mathrm{CH}_{3} \mathrm{CN}$ & 25 & 4 & 33 & 17 \\
\hline 6 & $\mathrm{CaCO}_{3}$ & $\mathrm{CH}_{3} \mathrm{CN}$ & 25 & 4 & 25 & 39 \\
\hline 7 & $\mathrm{Li}_{2} \mathrm{CO}_{3}$ & $\mathrm{CH}_{3} \mathrm{CN}$ & 25 & 4 & 27 & 29 \\
\hline 8 & $\mathrm{Na}_{2} \mathrm{CO}_{3}$ & DME & 25 & 4 & 19 & 24 \\
\hline 9 & $\mathrm{Na}_{2} \mathrm{CO}_{3}$ & DMF & 25 & 4 & 31 & 14 \\
\hline 10 & $\mathrm{Na}_{2} \mathrm{CO}_{3}$ & DMSO & 25 & 4 & 24 & 9 \\
\hline 11 & $\mathrm{Na}_{2} \mathrm{CO}_{3}$ & THF & 25 & 4 & 31 & 20 \\
\hline 12 & $\mathrm{Na}_{2} \mathrm{CO}_{3}$ & $\mathrm{CH}_{3} \mathrm{CN}$ & 50 & 4 & 66 & 5 \\
\hline 13 & $\mathrm{Na}_{2} \mathrm{CO}_{3}$ & $\mathrm{CH}_{3} \mathrm{CN}$ & 80 & 4 & $81(57)$ & 2 \\
\hline 14 & $\mathrm{Na}_{2} \mathrm{CO}_{3}$ & $\mathrm{CH}_{3} \mathrm{CN}$ & 80 & 8 & $83(60)$ & 0 \\
\hline 15 & $\mathrm{Na}_{2} \mathrm{CO}_{3}$ & $\mathrm{CH}_{3} \mathrm{CN}$ & 80 & 16 & $70(56)$ & $<1$ \\
\hline
\end{tabular}

aThe isolated yield is shown in parentheses.

Then, four types of ynones, $\mathbf{2 a - d}$, were reacted with formamidine and acetamidine as well as guanidine under the optimized conditions outlined above, the results of which are summarized in Table 6. When the reactions were performed with acetamidine and guanidine, a good to high yield was recorded, while only a lower yield was obtained by the application of formami-

Table 6: Preparation of trifluoromethylated pyrimidine derivatives 6.

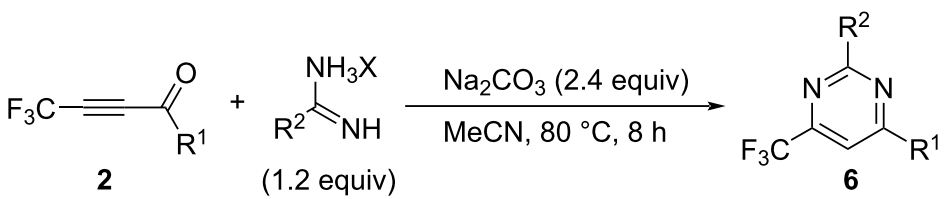

\begin{tabular}{|c|c|c|c|c|c|}
\hline entry & $\mathrm{R}^{1}$ & $\mathrm{R}^{2}$ & $x$ & product & isolated yield (\%) \\
\hline 1 & $\mathrm{Ph}(\mathbf{2 a})$ & $\mathrm{NH}_{2}$ & $\mathrm{Cl}$ & 6aa & 60 \\
\hline 2 & 4-(MeO) $\mathrm{C}_{6} \mathrm{H}_{4}(\mathbf{2 b})$ & $\mathrm{NH}_{2}$ & $\mathrm{Cl}$ & $6 a b$ & 55 \\
\hline 3 & $4-\mathrm{MeC}_{6} \mathrm{H}_{4}(2 \mathrm{c})$ & $\mathrm{NH}_{2}$ & $\mathrm{Cl}$ & $6 a c$ & 52 \\
\hline 4 & $4-\mathrm{BrC}_{6} \mathrm{H}_{4}(\mathbf{2 d})$ & $\mathrm{NH}_{2}$ & $\mathrm{Cl}$ & 6ad & 67 \\
\hline 5 & $\mathrm{Ph}(\mathbf{2 a})$ & Me & $\mathrm{Cl}$ & $6 \mathrm{ba}$ & 67 \\
\hline 6 & 4-(MeO) $\mathrm{C}_{6} \mathrm{H}_{4}(\mathbf{2 b})$ & $\mathrm{Me}$ & $\mathrm{Cl}$ & $6 b b$ & 75 \\
\hline 7 & $4-\mathrm{MeC}_{6} \mathrm{H}_{4}(2 \mathrm{c})$ & $\mathrm{Me}$ & $\mathrm{Cl}$ & $6 b c$ & 53 \\
\hline 8 & $4-\mathrm{BrC}_{6} \mathrm{H}_{4}(\mathbf{2 d})$ & $\mathrm{Me}$ & $\mathrm{Cl}$ & $6 b d$ & 57 \\
\hline 9 & $\mathrm{Ph}(\mathbf{2 a})$ & $\mathrm{H}$ & $\mathrm{AcO}$ & $6 c a$ & 21 \\
\hline 10 & 4-(MeO) $\mathrm{C}_{6} \mathrm{H}_{4}(\mathbf{2 b})$ & $\mathrm{H}$ & $\mathrm{AcO}$ & $6 c b$ & 28 \\
\hline 11 & $4-\mathrm{MeC}_{6} \mathrm{H}_{4}(2 \mathrm{c})$ & $\mathrm{H}$ & $\mathrm{AcO}$ & $6 c c$ & 22 \\
\hline 12 & $4-\mathrm{BrC}_{6} \mathrm{H}_{4}(\mathbf{2 d})$ & $\mathrm{H}$ & $\mathrm{AcO}$ & $6 \mathrm{~cd}$ & 26 \\
\hline
\end{tabular}


dine acetate, for which the reaction was not further elucidated at this point.

The unfavorable yield may be reasoned by the fact that there have been very limited reports for the syntheses of, for example, pyrimidine 6ca [35-38], with such drawbacks as the formation of a regioisomeric mixture [35] and the requirement of harsh conditions [38]. At the same time, for the use of a substrate similar to $2 \mathrm{a}$ where the $\mathrm{CF}_{3}$ and $\mathrm{Ph}$ groups were formally exchanged, an isolated yield of $84 \%$ has been recorded for $6 \mathbf{c a}$ [37]. Moreover, it is noteworthy that only one report dealt with the preparation of $\mathbf{6 c b}$ [37], and $\mathbf{6 c c}$ and $\mathbf{6} \mathbf{c d}$ have not been previously reported. Thus, including 6aa [37-40] and 6ba $[37,38,41,42]$, it is noteworthy to realize the construction of relatively rare pyrimidines in a concise fashion via the ynones 2 with a $\mathrm{CF}_{3}$ group.

\section{Conclusion}

As described above, we succeeded in the construction of 4,4,4-trifluorobut-2-yn-1-ones 2 by way of a convenient $\mathrm{MnO}_{2}$ oxidation of readily accessible propargylic alcohols $\mathbf{1}$. In spite of the application of this method only to $\mathbf{1}$, with an aromatic substituent at the propargylic position and the requirement of an excess amount of this oxidant, the practical convenience, low cost, as well as the clean conversion are notable features of this method, which is worthy of attention. Furthermore, the high electrophilicity of ynones $\mathbf{2}$ obtained was nicely demonstrated through two representative reactions, namely 1) Michael additions of $\beta$-keto carbonyl compounds and 2) amidines and guanidine for the construction of aromatic and heteroaromatic products, which successfully expanded this unique synthetic approach to compounds with a limited precedent. Further work is ongoing for the application of ynones 2 .

\section{Supporting Information}

The Supporting Information features the experimental part of this article.

\section{Supporting Information File 1}

General information, synthetic procedures, and spectral data.

[https://www.beilstein-journals.org/bjoc/content/ supplementary/1860-5397-17-14-S1.pdf]

\section{ORCID ${ }^{\circledR}$ iDs}

Takashi Yamazaki - https://orcid.org/0000-0002-1460-3086 Tomoko Kawasaki-Takasuka - https://orcid.org/0000-0002-8468-7553

\section{References}

1. Inoue, M.; Sumii, Y.; Shibata, N. ACS Omega 2020, 5, 10633-10640. doi:10.1021/acsomega.0c00830

2. Mei, H.; Han, J.; Fustero, S.; Medio-Simon, M.; Sedgwick, D. M.; Santi, C.; Ruzziconi, R.; Soloshonok, V. A. Chem. - Eur. J. 2019, 25, 11797-11819. doi:10.1002/chem.201901840

3. Wang, J.; Sánchez-Roselló, M.; Aceña, J. L.; del Pozo, C.; Sorochinsky, A. E.; Fustero, S.; Soloshonok, V. A.; Liu, H. Chem. Rev. 2014, 114, 2432-2506. doi:10.1021/cr4002879

4. Mizutani, K.; Yamazaki, T.; Kitazume, T. J. Chem. Soc., Chem. Commun. 1995, 51-52. doi:10.1039/c39950000051

5. Yamazaki, T.; Mizutani, K.; Kitazume, T. J. Org. Chem. 1995, 60, 6046-6056. doi:10.1021/jo00124a013

6. Miyagawa, A.; Naka, M.; Yamazaki, T.; Kawasaki-Takasuka, T. Eur. J. Org. Chem. 2009, 4395-4399. doi:10.1002/ejoc.200900370

7. Yamazaki, T.; Ichige, T.; Kitazume, T. Org. Lett. 2004, 6, 4073-4076. doi:10.1021/ol048229x

8. Yamazaki, T.; Yamamoto, T.; Ichihara, R. J. Org. Chem. 2006, 71, 6251-6253. doi:10.1021/jo060909l

9. Yamazaki, T.; Kawasaki-Takasuka, T.; Furuta, A.; Sakamoto, S. Tetrahedron 2009, 65, 5945-5948. doi:10.1016/j.tet.2009.05.087

10. Watanabe, Y.; Yamazaki, T. Synlett 2009, 3352-3354. doi:10.1055/s-0029-1218383

11. Watanabe, Y.; Yamazaki, T. J. Fluorine Chem. 2010, 131, 646-651. doi:10.1016/j.jfluchem.2010.01.003

12. Watanabe, Y.; Yamazaki, T. J. Org. Chem. 2011, 76, 1957-1960. doi:10.1021/jo102503s

13. Yamazaki, T.; Watanabe, Y.; Yoshida, N.; Kawasaki-Takasuka, T. Tetrahedron 2012, 68, 6665-6673. doi:10.1016/j.tet.2012.05.131

14. Ichikawa, T.; Kawasaki-Takasuka, T.; Yamada, S.; Yamazaki, T.; Kubota, T. J. Fluorine Chem. 2013, 152, 38-45. doi:10.1016/j.jfluchem.2012.10.013

15. Shen, Y.; Xin, Y.; Cen, W.; Huang, Y. Synthesis 1984, 35-37. doi:10.1055/s-1984-30723

16. Bumgardner, C. L.; Bunch, J. E.; Whangbo, M. H. J. Org. Chem. 1986, 51, 4082-4083. doi:10.1021/jo00371a037

17. Chechulin, P. I.; Filyakova, V. I.; Pashkevich, K. I. Bull. Acad. Sci. USSR, Div. Chem. Sci. (Engl. Transl.) 1989, 38 , 189-190. doi:10.1007/bf00953736

18. Tajammal, S.; Tipping, A. E. J. Fluorine Chem. 1990, 47, 45-57. doi:10.1016/s0022-1139(00)80446-7

19. Brisdon, A. K.; Crossley, I. R. Chem. Commun. 2002, 2420-2421. doi:10.1039/b207979h

20. Wang, T.; Niu, D.; Hoye, T. R. J. Am. Chem. Soc. 2016, 138, 7832-7835. doi:10.1021/jacs.6b03786

21. Murray, B. J.; Marsh, T. G. F.; Yufit, D. S.; Fox, M. A.; Harsanyi, A.; Boulton, L. T.; Sandford, G. Eur. J. Org. Chem. 2020, 6236-6244. doi:10.1002/ejoc.202001071

22. Ishihara, T.; Yamasaki, Y.; Ando, T. Tetrahedron Lett. 1985, 26, 79-82. doi:10.1016/s0040-4039(00)98472-7

23. Sibous, L.; Tipping, A. E. J. Fluorine Chem. 1993, 62, 39-49. doi:10.1016/s0022-1139(00)80079-2

24. Fouli, F. A.; Basyouni, M. N. Acta Chim. Acad. Sci. Hung. 1981, 106, 297-302.

25. Shankar, R.; Jha, A. K.; Singh, U. S.; Hajela, K. Tetrahedron Lett. 2006, 47, 3077-3079. doi:10.1016/j.tetlet.2006.03.008

26. Ramachary, D. B.; Venkaiah, C.; Murali Krishna, P. Chem. Commun. 2012, 48, 2252-2254. doi:10.1039/c2cc17219d 
27. Tong, W.; Li, Q.-Y.; Xu, Y.-L.; Wang, H.-S.; Chen, Y.-Y.; Pan, Y.-M. Adv. Synth. Catal. 2017, 359, 4025-4035.

doi:10.1002/adsc.201700830

28. Yuan, Y.; Guo, Z.; Mu, Y.; Wang, Y.; Xu, M.; Li, Y. Adv. Synth. Catal. 2020, 362, 1298-1302. doi:10.1002/adsc.201901631

29. Ramasamy, M.; Lin, H.-C.; Kuo, S.-C.; Hsieh, M.-T. Synlett 2019, 30 , 356-360. doi:10.1055/s-0037-1611694

30. Guan, H.-P.; Hu, C.-M. J. Fluorine Chem. 1996, 78, 101-102. doi:10.1016/0022-1139(96)03407-0

31. Furuta, T.; Nakayama, M.; Suzuki, H.; Tajimi, H.; Inai, M.; Nukaya, H.; Wakimoto, T.; Kan, T. Org. Lett. 2009, 11, 2233-2236. doi:10.1021/ol900689m

32. Wang, X.-j.; Zhang, L.; Byrne, D.; Nummy, L.; Weber, D.; Krishnamurthy, D.; Yee, N.; Senanayake, C. H. Org. Lett. 2014, 16 , 4090-4093. doi:10.1021/ol501755h

33. Matsuda, T.; Matsumoto, T. Org. Biomol. Chem. 2016, 14, 5023-5027. doi:10.1039/c6ob00734a

34. Nenajdenko, V. G., Ed. Fluorine in Heterocyclic Chemistry; Springer: Berlin, Germany, 2014; Vol. 1 and 2.

35. Gupta, S.; Melanson, J. A.; Vaillancourt, L.; Nugent, W. A.; Tanoury, G. J.; Schatte, G.; Snieckus, V. Org. Lett. 2018, 20, 3745-3748. doi:10.1021/acs.orglett.8b01300

36. Geri, J. B.; Wade Wolfe, M. M.; Szymczak, N. K. Angew. Chem., Int. Ed. 2018, 57, 1381-1385. doi:10.1002/anie.201711316

37. Romanov, A. R.; Rulev, A. Y.; Ushakov, I. A.; Muzalevskiy, V. M.; Nenajdenko, V. G. Eur. J. Org. Chem. 2017, 4121-4129. doi:10.1002/ejoc.201700727

38. Saijo, R.; Watanabe, G.; Kurihara, K.-i.; Kawase, M. Heterocycles 2014, 89, 2334-2345. doi:10.3987/com-14-13075

39. Liu, C.; Cui, Z.; Yan, X.; Qi, Z.; Ji, M.; Li, X. Molecules 2016, 21, 828. doi: $10.3390 /$ molecules 21070828

40. Rawal, R. K.; Tripathi, R.; Katti, S. B.; Pannecouque, C.; De Clercq, E. Bioorg. Med. Chem. 2007, 15, 3134-3142. doi:10.1016/j.bmc.2007.02.044

41. Funabiki, K.; Nakamura, H.; Matsui, M.; Shibata, K. Synlett 1999, 756-758. doi:10.1055/s-1999-2741

42. Jeong, I. H.; Jeon, S. L.; Kim, M. S.; Kim, B. T. J. Fluorine Chem. 2004, 125, 1629-1638. doi:10.1016/j.jfluchem.2004.09.021

\section{License and Terms}

This is an Open Access article under the terms of the Creative Commons Attribution License (https://creativecommons.org/licenses/by/4.0). Please note that the reuse, redistribution and reproduction in particular requires that the author(s) and source are credited and that individual graphics may be subject to special legal provisions.

The license is subject to the Beilstein Journal of Organic Chemistry terms and conditions:

(https://www.beilstein-journals.org/bjoc/terms)

The definitive version of this article is the electronic one which can be found at:

https://doi.org/10.3762/bjoc.17.14 